J. Clin. Chem. Clin. Biochem.

Vol. 27, 1989, pp. 847-850

(C) 1989 Walter de Gruyter \& Co. Berlin - New York

\title{
The Effect of Oral Calcium Load or Verapamil on Gentamicin-Induced Nephrotoxicity
}

\author{
By A. Tamir
}

The Pediatric Division, Assaf Harofeh Medical Center

Bat-ami Israeli

The Kimron Veterinary Institute, Sackler School of Medicine of Tel-Aviv University, Israel

\author{
M. Aladjem
}

The Pediatric Division, Assaf Harofeh Medical Center and

\section{E. Bogin}

The Kimron Veterinary Institute, Sackler School of Medicine of Tel-Aviv University, Israel

(Received January 9/July 27, 1989)

Summary: Several investigators have reported recently that in rats, oral calcium load is associated with a marked amelioration in gentamicin-induced renal failure. In contrast to these reports, using the same animal model, we could not observe calcium-induced moderation in gentamicin nephrotoxicity as reflected by either urea or creatinine serum concentration or by various renal cortical intracellular enzymatic activities. Similarly, verapamil, a calcium channel blocker, had no effect on the degree of renal failure in these animals. We conclude that manipulation of calcium diet may not be uniformly effective in reducing gentamicin nephrotoxicity. Additional nutritional factors may play a crucial role in achieving the amelioration of this model of toxic nephropathy.

\section{Introduction}

Nephrotoxicity due to aminoglycoside treatment is a known clinical complication (1). Lietman et al. (2) showed a fall in creatinine clearance in $15 \%$ of 214 patients treated with aminoglycosides. Factors that can reduce nephrotoxicity are of great importance as they may enâble the use of aminoglycosides with minimal adverse effects (3). In the last decade several investigators have demonstrated that dietary calcium supplementation ameliorated gentamicin-induced renal failure $(4-6)$. The protective mechanism was attributed, at least in part, to a calcium-mediated competitive inhibition of gentamicin binding and uptake along the renal proximal tubular brush border membrane (4). Another aspect of calcium metabolism in uraemia, namely nephrocalcinosis, was recently investigated by Goligorsky et al. (7), who found that verapamil prevents renal accumulation of calcium in uraemic rats.

The aim of the present study was:

a) to investigate the effect of calcium loading on the severity of gentamicin-induced renal failure and its impact on various intracellular renal cortical enzyme activities,

b) to evaluate the effects of verapamil on this model of toxic nephropathy. 


\section{Materials and Methods}

Male Sprague Dawley rats 6-8 week old, weighing 150-200 g were used for all studies. Animals were divided into six groups (tab. 1).

Each group consisted of at least 12 animals. After 10 days all rats were sacrificed. Blood for the various examinations was drawn from the aorta. The serum was analysed for creatinine, calcium, phosphorus and magnesium concentration. The kidneys were removed and processed for biochemical analysis. The renal cortex was placed in a $0.02 \mathrm{~mol} / 1$ Tris $\mathrm{HCl}, \mathrm{pH} 7.4$ buffer (1:10 weight to volume ratio) and homogenized in a PotterEliehjem Glass Teflon homogenizer at $0-4{ }^{\circ} \mathrm{C}$. The homogenate was centrifuged in a Sorvall $\mathrm{RC} 2 \mathrm{~B}$ centrifuge at $0-4^{\circ} \mathrm{C}$ and the various cellular constituents were obtained by using different centrifugal speeds according to a procedure previously described (8).

\section{Enzyme assays}

Aspartate aminotransferase (EC 2.6.1.1), alanine aminotransferase (EC 2.6.1.2), $L$-iditol dehydrogenase (EC 1.1.1.14) and orthophosphoric-monoester phosphohydrolase (alkaline optimum) (EC 3.1.3.1) of the homogenate and serum were measured spectrophotometrically with a Gilford Autoanalyser at $30^{\circ} \mathrm{C}$ by methods previously described $(8,9)$. Details of reaction and performance characteristics (within run and run to run) are given (10). Protein content was determined according to Lowry et al. (11) Urea was determined enzymatically, according to Talke \& Schubert (12) and creatinine according to Fabiny \& Ertingshausen (13). The gentamicin bioassay described by Bennet et al. (14) was performed with Muller Hinton Agar plates at pH 8.0, using Bacillus subtilis strain AATC 6633; the analytical range was $0.05-3 \mathrm{mg} / \mathrm{l}$ with $\mathrm{CV}<2.0 \%$ at $1.5 \mathrm{mg} / \mathrm{l}$.

Statistical analysis was performed using Student's t test and also by analysis of variance. The results are given in mean \pm S. E. M.

\section{Results}

Mean urea and creatinine concentrations were similar in the control (Group 1), high calcium diet (Group 3) or verapamil treated (Group 5) rats. The administration of gentamicin resulted in severe renal failure as manifested by the significant increase in serum urea and creatinine concentrations. Neither oral calcium load nor verapamil had any significant attenuating effect on the degree of renal failure (tab. 2).

Mean activities of sorbitol dehydrogenase, alkaline phosphatase, aspartate aminotransferase and alanine aminotransferase in renal tissue were similar in groups 1, 3 and 5. Treatment with gentamicin was associated with a significant reduction in the activities of these enzymes. The addition of calcium or verapamil did not result in any appreciable attenuation in gentamicin-induced nephrotoxicity (tab. 3).

The relationship between serum urea and creatinine (both reliable markers of glomerular filtration rate) and cellular enzyme activities was investigated. Both serum urea and creatinine showed highly significant inverse correlations with the activities of cellular aspartate aminotransferase, alanine aminotransferase, sorbitol dehydrogenase, alkaline phosphatase and lactate dehydrogenase (tab. 4).

No significant decrease was observed in renal tissue gentamicin concentration in rats treated with either oral calcium load or verapamil (tab. 5).

Tab. 1. Experimental design.

\begin{tabular}{|c|c|c|c|}
\hline No. & Group name & Diet & Subcutaneous injection treatment \\
\hline 1 & $\mathrm{C}=$ control & Standard rat chow & $\begin{array}{l}\text { Twice daily saline } 0.2 \mathrm{ml} \text { at } 08.00 \mathrm{~h} \text { and } \\
16.00 \mathrm{~h} \text {. }\end{array}$ \\
\hline 2 & $\mathrm{G}=$ Gentamicin & Standard rat chow & $\begin{array}{l}\text { Gentamicin } 100 \mathrm{mg} / \mathrm{kg} \text { body weight at } 08.00 \mathrm{~h} \\
\text { and } 0.2 \mathrm{ml} \text { saline at } 16.00 \mathrm{~h}\end{array}$ \\
\hline 3 & $\mathrm{Ca}=$ Calcium & $\begin{array}{l}\text { Standard rat chow* enriched by } \\
\mathrm{CaCO}_{3} 40 \mathrm{~g} / \mathrm{l}, \mathrm{Ca} \text {-gluconate } 5 \mathrm{~g} / \mathrm{l} \text { in } \\
\text { drinking water. }\end{array}$ & $\begin{array}{l}\text { Twice daily saline } 0.2 \mathrm{ml} \text { at } 08.00 \mathrm{~h} \text { and } \\
16.00 \mathrm{~h} \text {. }\end{array}$ \\
\hline 4 & $\begin{array}{l}\mathrm{G}+\mathrm{Ca}=\text { Gentamicin }+ \\
\text { Calcium }\end{array}$ & $\begin{array}{l}\text { Standard rat chow* enriched by } \\
\mathrm{CaCO}_{3} 40 \mathrm{~g} / \mathrm{l} \text {, Ca-gluconate } 5 \mathrm{~g} / \mathrm{l} \text { in } \\
\text { drinking water. }\end{array}$ & $\begin{array}{l}\text { Gentamicin } 100 \mathrm{mg} / \mathrm{kg} \text { body weight at } 08.00 \mathrm{~h} \\
\text { and } 0.2 \mathrm{ml} \text { saline at } 16.00 \mathrm{~h} .\end{array}$ \\
\hline 5 & $\mathrm{~V}=$ Verapamil & Standard rat chow & $\begin{array}{l}\text { Verapamil } 2.5 \mathrm{mg} / \mathrm{kg} \text { body weight at } 08.00 \mathrm{~h} \\
\text { and } 16.00 \mathrm{~h} \text {. }\end{array}$ \\
\hline 6 & $\begin{array}{l}\mathrm{G}+\mathrm{V}=\text { Gentamicin }+ \\
\text { Verapamil }\end{array}$ & Standard rat chow & $\begin{array}{l}\text { Verapamil } 2.5 \mathrm{mg} / \mathrm{kg} \text { body weight at } 08.00 \mathrm{~h} \\
\text { and } 16.00 \mathrm{~h} \text { and gentamicin } 100 \mathrm{mg} / \mathrm{kg} \text { body } \\
\text { weight at } 08.00 \mathrm{~h} \text {. }\end{array}$ \\
\hline
\end{tabular}

* Calcium enrichment started 24 hours before gentamicin treatment.

Tab. 2. Urea $(\mathrm{mmol} / \mathrm{l})$ and creatinine $(\mu \mathrm{mol} / \mathrm{l})$ concentration in the various groups $(x \pm S E M)$.

\begin{tabular}{|c|c|c|c|c|c|c|c|}
\hline . & $\begin{array}{l}\text { Gr 1 } \\
(C) \\
n=12\end{array}$ & $\begin{array}{l}\text { Gr } 2 \\
(G) \\
n=14\end{array}$ & $\begin{array}{l}\mathrm{Gr} 3 \\
(\mathrm{Ca}) \\
\mathrm{n}=12\end{array}$ & $\begin{array}{l}\mathrm{Gr} 4 \\
(\mathrm{G}+\mathrm{Ca}) \\
\mathrm{n}=14\end{array}$ & $\begin{array}{l}\mathrm{Gr} 5 \\
(\mathrm{~V}) \\
\mathrm{n}=12\end{array}$ & ; & $\begin{array}{l}G r 6 \\
(G+V) \\
n=14\end{array}$ \\
\hline $\begin{array}{l}\text { Urea } \\
\text { Creatinine }\end{array}$ & $\begin{array}{c}7.1 \pm 0.4 \\
74 \pm 10\end{array}$ & ${ }_{402}^{38.6 \pm} \pm 56^{*}$ & $67 \pm 0.8 \pm 0.3$ & $\begin{array}{c}33.5 \pm 4.5^{*} \\
310 \pm 56^{*}\end{array}$ & $\begin{array}{l}6.6 \pm 0.3 \\
68 \pm 7\end{array}$ & & $\begin{array}{l}3 \overline{7} .3 \pm \\
349 \pm 50^{*}\end{array}$ \\
\hline
\end{tabular}

* Significance $\mathrm{P}<0.001$ for gentamicin addition. 
Tab. 3. Renal cortex cellular enzyme values in the various groups (International Units/g protein).

\begin{tabular}{|c|c|c|c|c|c|c|}
\hline & $\begin{array}{l}\text { Gr } 1 \\
(C) \\
n=12\end{array}$ & $\begin{array}{l}\text { Gr } 2 \\
(G) \\
n=14\end{array}$ & $\begin{array}{l}\text { Gr } 3 \\
(\mathrm{Ca}) \\
\mathrm{n}=12\end{array}$ & $\begin{array}{l}\mathrm{Gr} 4 \\
(\mathrm{G}+\mathrm{Ca}) \\
\mathrm{n}=14\end{array}$ & $\begin{array}{l}\text { Gr } 5 \\
(V) \\
n=12\end{array}$ & $\begin{array}{l}G+6 \\
(G+V) \\
n=14\end{array}$ \\
\hline $\begin{array}{l}\text { Alkaline } \\
\text { phosphatase }\end{array}$ & $174 \pm 16$ & $53 \pm 6^{*}$ & $183 \pm 15$ & $65 \pm 8^{*}$ & $171 \pm 11$ & $58 \pm 6^{*}$ \\
\hline $\begin{array}{l}\text { Alanine } \\
\text { aminotransferase }\end{array}$ & $29 \pm 1.3$ & $17 \pm 1.5^{*}$ & $29 \pm 1.2$ & $19 \pm 1.2^{*}$ & $30 \pm 1.3$ & $17 \pm 1.1^{*}$ \\
\hline $\begin{array}{l}\text { Sorbitol } \\
\text { dehydrogenase }\end{array}$ & $121 \pm 10$ & $41 \pm 6^{*}$ & $129 \pm 12$ & $50 \pm 8^{*}$ & $135 \pm 9$ & $43 \pm 6^{*}$ \\
\hline $\begin{array}{l}\text { Aspartate } \\
\text { aminotransferase }\end{array}$ & $469 \pm 11$ & $307 \pm 24^{*}$ & $480 \pm 12$ & $347 \pm 21^{*}$ & $480 \pm 16$ & $336 \pm 15^{*}$ \\
\hline $\begin{array}{l}\text { Lactate } \\
\text { dehydrogenase }\end{array}$ & $1360 \pm 50$ & $1070 \pm 60^{*}$ & $1510 \pm 50$ & $1320 \pm 60^{*}$ & $1510 \pm 60$ & $1270 \pm 30^{*}$ \\
\hline
\end{tabular}

* Significance $P<0.001$, for gentamicin addition.

Tab. 4. Correlation coefficients relating urea and creatinine values in serum to tissue enzyme values.

\begin{tabular}{lll}
\hline & Urea & Creatinine \\
\hline Aspartate aminotransferase & -0.82 & -0.75 \\
Alanine aminotransferase & -0.76 & -0.66 \\
Sorbitol dehydrogenase & -0.82 & -0.74 \\
Alkaline phosphatase & -0.79 & -0.73 \\
Lactate dehydrogenase & -0.66 & -0.65 \\
\hline
\end{tabular}

Probability $<0.0001$ for all these correlations.

\section{Discussion}

Nephrotoxicity is a major adverse effect of aminoglycoside antibiotic agents. The renal dysfunction due to gentamicin treatment in humans has been related to several risk factors $(2,3,15,16)$. The precise intracellular targets that are affected by these agents, leading to renal damage are uncertain. Plasma membrane and lysosomal phospholipases, basolateral membrane $\mathrm{Na}^{+}-\mathrm{K}^{+}$-ATPase and mitochondrial membranes have been proposed $(17-20)$. Recently gentamicin-induced decreases in mitochondrial cytochrome enzyme concentrations were observed, suggesting the possibility that the renal tubular cell protein synthetic mechanisms are disturbed by this agent (21).

The wide use of these antibiotic agents and their major contribution in the treatment of various infectious processes have initiated a search for treatment modalities which may eliminate or ameliorate their neph- rotoxic effect. It has been shown that hydroxyl radical scavengers such as dimethylthiourea, dimethyl sulphoxide and sodium benzoate or deferoxamine (a potent iron chelator) may moderate the gentamicininduced renal failure in rats (22).

Several investigators have demonstrated that the administration of calcium to rats also ameliorated gentamicin nephrotoxicity $(4-6)$. The mechanism by which this phenomenon is achieved is unclear. It has been suggested that calcium may act as a competitive inhibitor, modifying gentamicin interaction with critical subcellular membrane sites of the renal proximal tubule (6).

In the present study the administration of gentamicin to rats was associated with severe nephrotoxicity as evidenced by impairment of both kidney function (increased urea and creatinine) and metabolism (decrease in various cellular enzymatic activities). In agreement with others (4-6) a high calcium diet was not associated with a lower gentamicin concentration in the renal cortex. However, in contrast to previous reports $(2-4)$, we did not observe any significant amelioration in the degree of nephrotoxicity. This difference in observations can not be explained on a basis of different protocols. Calcium concentration in the diet was similar to that used by others $(4-6)$. The time elapsing between the initiation of calcium loading and the administration of gentamicin, and the dosage of gentamicin were identical to those of a previously used study protocol (6).

Tab. 5. Gentamicin values (mg/g protein) in rẹnal tissue.

\begin{tabular}{|c|c|c|c|c|c|c|}
\hline . & $\begin{array}{l}\text { Gr } 1 \\
(C) \\
n=12\end{array}$ & $\begin{array}{l}\text { Gr } 2 \\
(G) \\
n=14\end{array}$ & $\begin{array}{l}\mathrm{Gr} 3 \\
(\mathrm{Ca}) \\
\mathrm{n}=12\end{array}$ & $\begin{array}{l}\mathrm{Gr} 4 \\
(\mathrm{G}+\mathrm{Ca}) \\
\mathrm{n}=14\end{array}$ & $\begin{array}{l}\text { Gr } 5 \\
(V) \\
n=12\end{array}$ & $\begin{array}{l}\text { Gr } 6 \\
(G+V) \\
n=14\end{array}$ \\
\hline Gentamicin & 0 & $39.8 \pm 3.9$ & 0 & $35.8 \pm 3.1$ & 0 & $39.1 \pm 3.6$ \\
\hline
\end{tabular}


It has been shown that calcium loading in the presence of high sodium intake-induced volume expansion, may not be protective against renal cell injury caused by gentamicin (6). Dietary restriction of protein intake may also moderate to some degree aminoglycoside nephrotoxicity (23). We did not monitor the sodium or protein intake. It may well be that the differing results in our study at least in part, reflect nutritional factors.

Nephrocalcinosis is a common complication of the uraemic state and may play a decisive role in its progression. Gentamicin nephrotoxicity is associated with a significant increase in cellular calcium concentration $(6,24)$. The main site of its accumulation seems to be within the mitochondria (24). Recently it has been shown that verapamil, a potent calcium-channel blocker may prevent nephrocalcinosis (7). In our study we could not demonstrate any amelioration of gentamicin-induced nephrotoxicity by either kidney

\section{References}

1. Appel, G. B. \& Neu, H. C. (1977) The nephrotoxicity of antimicrobial agents. N. Engl. J. Med. 296, 722-728.

2. Moore, R. D., Smith, C. R., Lipsky, J. J., Mellits, E. D. \& Lietman, P. S. (1984). Risk factors for nephrotoxicity in patients treated with aminoglycosides. Ann. Intern. Med. $100,352-357$.

3. Smith, C. R., Lipsky, J. J., Laskin, O. L., Hellman, D. B., Mellits, E. D., Longstreth, J. \& Lietman, P. S. (1980) Double blind comparison of the nephrotoxicity and auditory toxicity of Gentamicin and Tobramycin. N. Engl. J. Med. 320, 1106-1109.

4. Bennett, W. M., Elliott, W. C., Houghton, D. C., Gilbert, D. N., Defehr, J. \& Mc Carron, D. A. (1982) Reduction of experimental gentamicin nephrotoxicity in rats by dietary calcium loading. Antimicrobial Agents and Chemotherapy, $22508-512$.

5. Quarum, M. L., Houthton, D. C., Gilbert, D. N., Mc Carron, D. A. \& Bennett, W. M. (1984) Increasing dietary calcium moderates experimental gentamicin nephrotoxicity. J. Lab. Clin. Med. 103, 104-114.

6. Humes, H. D., Sastrasinh, M. \& Weinberg, J. M. (1984) Calcium is a competitive inhibitor of gentamicin renal membrane binding interactions and dietary calcium supplementation protects against gentamicin nephrotoxicity. J. Clin. Invest. 73, 134-147.

7. Goligorsky, M. S., Chaimovitz, C., Rapoport, J., Goldstein, J. \& Kol, R. (1985) Calcium metabolism in uremic nephrocalcinosis, preventive effect of verapamil. Kidney International 27, 774-779.

8. Bogin, E. \& Israeli, B. (1976) Enzyme profile of heart and skelatal muscles, liver and lungs of roosters and geese. $\mathrm{Zbl}$. Vet. Med. 23, 152-157.

9. Bergmeyer, H. U. \& Gawehn, K. (1974) Methods of enzymatic analysis 2 nd ed. Acad. Press, New York \& London, pp. $512-513,733-735,758-760,860-863$.

10. Gilford Operation Mannual System (1980) 203-205.

11. Lowry, O., Rosebrough, N. J., Farr, A. L. \& Randall, R. I. (1951) Protein measurements with the Folin phenol reagent. J. Biol. Chem. 193, 265-275.

12. Talke, H. \& Schubert, G. E. (1965) Enzymatische Harnstoffbestimmung in Blut und Serum im optischen Test nach Warburg. Klin. Wochenschr. 43, 174-179. function indices or enzymatic-metabolic ones. The administration of verapamil also had no effect on renal tissue gentamicin concentration. Of special interest are the significant correlations between renal function indices such as urea and creatinine, and various enzyme activities. These inverse relationships, which to the best of our knowledge have never been reported previously, demonstrate the direct dependence of glomerular filtration on enzymatic metabolic activities.

We conclude that oral calcium supplementation does not ameliorate gentamicin-induced nephrotoxicity, unless other metabolic or nutritional factors are strictly controlled. Calcium channel blockers do not prevent or moderate the gentamicin-induced renal failure. Changes in metabolism, as reflected by a marked reduction in intracellular enzyme activities, correlate significantly with the degree of gentamicininduced impairment in glomerular filtration.

13. Fabiny, D. L. \& Ertingshausen, G. (1971) Automated reaction rate method for determination of serum creatinine. Clin. Chem. 17, 696 - 700.

14. Bennett, J. V., Brodie, J. L., Benner, E. J. \& Kerby, W. M. (1966) Simplified accurate method for antibiotic assay of clinical specimens. Applied Microbiology 14, 170-177.

15. Lietman, P. S. \& Smith, C. R. (1983) Aminoglycōside nephrotoxicity in humans. Rev. Infect. Dis. Vol. 5. Suppl. 2, 5284-5293.

16. Moore, R. D., Smith, C. R. \& Lietman, P. S. (1986) Increased risk of renal dysfunction due to interaction of liver disease and aminoglycosides. Am. J. Med. 80, 1093-1097.

17. Powell, J. H. \& Reidenberg, M. M. (1982) In vitro response of rat and human kidney lysosmes to aminoglycosides. Biochem. Pharmacol. 31, 3447-3453.

18. Tulkens, G. A., VanHoff, F. \& Tulkens, P. (1979) Gentamicin induced lysosomal phospholipidosis in cultured rat fibroblasts. Lab. Invest. 40, $481-491$.

19. Weinberg, J. M. \& Humes, H. D. (1982) Mechanisms of gentamicin induced dysfunction of renal cortical mitochondria. I. Effects of mitochondrial respiration. Arch. Biochem. Biophys. 205, 232-237.

20. Williams, P. D., Holohan, P. D. \& Ross, C. R. (1981) Gentamicin nephrotoxicity. I. Acute biochemical correlates in the rat. Toxicol. Appl. Pharmacol. 61, 234-242.

21. Bennett, W. M., Mela-Riker; L. M., Houghton, D. C., Gilbert, D. N. \& Buss, W. C. (1988) Microsomal protein synthesis inhibition: an early manifestation of gentamicin nephrotoxicity. Am. J. Physiol. 255, 266-269.

22. Walker, P. D. \& Sudhir, V. Shan (1988) Evidence suggesting a role for hydroxyl radical in gentamicin-induced acute renal failure in rats. J. Clin. Invest. 81, 334-341.

23. Whiting, P. H., Power, D. A., Petersen, J., Innes, A., Simpson, J. G. \& Catto, G. R. D. (1988) The effect of dietary protein restriction on high dose gentamicin nephrotoxicity in rats. Br. J. Exp. Pathol. 69, 35-41.

24. Weinberg, J. M. (1986) Aminoglycoside nephrotoxicity: The role of cell calcium overload in nephrotoxic renal tubular cell injury. Am. J. Kidney Diseases 8, 284-291.

\author{
E. Bogin \\ Kimron Institute \\ P. O. Box 12 \\ Bet Dagan, Israel 50250 .
}

